\title{
Inpatient experience of anorexia nervosa
}

\author{
Rachael Bellair ${ }^{1 *}$, Susan Patterson ${ }^{1}$, Esben Strodl ${ }^{2}$ \\ From 2014 ANZAED Conference: Driven Bodies Driven Brains \\ Fremantle, Australia. 22-23 August 2014
}

\begin{abstract}
Anorexia nervosa (AN) is an extremely serious mental illness, with a high mortality rate and many debilitating physical and psychological symptoms. While hospitalisation is sometimes required for patients with AN there remains no evidence base for "best practice' inpatient treatment. With patients' views recognised as critical to improving efficiency and outcomes, calls have been made for more qualitative research into inpatients' experiences. In light of this the current paper utilised thematic analysis to examine 16 semi-structured interviews with inpatients diagnosed with $\mathrm{AN}$, at a specialised eating disorders hospital unit. The study found an overarching theme of relationship ambivalence in connection with sub-themes of patients' eating disorders, eating disorder co-patients, staff and treatment. Participants' goals in relationship to their eating disorder and engagement in treatment shaped and were shaped by interactions with other inpatients with AN and staff. Clinical implications for this study and future research directions are discussed.
\end{abstract}

\section{Authors' details}

${ }^{1}$ Metro North Mental Health, Royal Brisbane and Women's Hospital, Brisbane,

Australia. ${ }^{2}$ Queensland University of Technology, Brisbane, Australia.

Published: 24 November 2014

\footnotetext{
* Correspondence: rachael.bellair@health.qld.gov.au

'Metro North Mental Health, Royal Brisbane and Women's Hospital, Brisbane, Australia

Full list of author information is available at the end of the article
}

Submit your next manuscript to BioMed Central and take full advantage of:

- Convenient online submission

- Thorough peer review

- No space constraints or color figure charges

- Immediate publication on acceptance

- Inclusion in PubMed, CAS, Scopus and Google Scholar

- Research which is freely available for redistribution 